\title{
Learning from alternative schools to enhance school completion
}

\author{
Kitty te Riele ${ }^{\mathrm{a}}$, Glenda McGregor ${ }^{\mathrm{b}}$, Martin Mills ${ }^{\mathrm{c}}$, Aspa Baroutsis ${ }^{\mathrm{b}}$, and Debra
}

Hayes $^{\mathrm{d}}$

\author{
${ }^{a}$ University of Tasmania, ${ }^{b}$ Griffith University, ${ }^{c}$ Queensland University of Technology, \\ ${ }^{d}$ University of Sydney
}

Summary

International organizations, such as the Organisation for Economic Co-operation and Development (OECD), as well as governments in OECD member countries are implementing policies aimed at increasing secondary school completion rates. Some decades ago, the senior secondary years were an exclusive option for an elite minority. Now, a common expectation is that they will cater to $90 \%$ or so of young people.

However, too often the practices in contemporary schooling contexts have not kept up with this change. In particular, there is extensive evidence that concerning numbers of socially and educationally marginalized students are rejected by, and themselves reject, mainstream schooling. As a result, in many jurisdictions alternative educational provision has been central to re-engaging young people and enabling their secondary school completion. Such provision includes "flexible," "second-chance," or "alternative" schools that, although not all the same, often have in common an inclusive and democratic approach to educating young people who have not been well served in mainstream schools.

Rather than such alternative schools being seen only as a useful "stop-gap" measure for marginalized students, they offer a valuable opportunity to re-imagine education. Such sites demonstrate structural, relational, and curricular changes that enable a range of education and learning options. First, in terms of structures, practical support and wraparound services are central to removing or alleviating structural barriers and clearing a path for learning. Second, supportive relationships are significant in enhancing the quality of young people's educational experiences and outcomes. In particular, connectedness and partnerships are key factors. Finally, a diverse curriculum is needed to facilitate an education that is meaningful and authentic, and builds the capabilities young people need in the 21 st century.

Initiatives aimed at speaking more meaningfully to young people who have traditionally been poorly served by schooling are at the core of many alternative schools, but they are also present in outstanding mainstream schools. These innovations offer inspiration for reform across all schools, for all students. Embedding such reform through broad systemic change in mainstream schooling is necessary to facilitate an education for all young people that is: meaningful in holistic ways, democratic and respectful, supportive and enabling, and equips them with the skills and knowledge to progress their hopes, dreams, and imagined futures.

Keywords: alternative education, school retention, school completion, school exclusion, marginalized students 
te Riele, K., McGregor, G., Mills, M., Baroutsis, A., \& Hayes, D. (2020, December 17). Learning from alternative schools to enhance school completion. In Oxford Research Encyclopaedia of Education. Oxford University Press.

doi: https://doi.org/10.1093/acrefore/9780190264093.013.513

\section{Introduction}

A policy consensus is evident, especially among "Western" post-industrialized nations, that educational attainment needs to be lifted both to service the knowledge economy and as a measure to address high levels of youth unemployment (Lyche, 2010; OECD, 2010, 2012, 2017). In particular, senior secondary education - once the preserve of an elite minority destined for university study - has become a new minimum expectation across OECD member countries. In her report for the Organisation for Economic Co-operation and Development (OECD), Lyche suggests:

Non-completion of upper secondary education and training has immense consequences not only for the individuals concerned but for the societies they live in. Completing upper secondary is a necessity to ensure full participation in civic life and to ensure better chances in the labour market. Early school leavers across OECD countries on average earn less and have higher unemployment rates than those who complete. (Lyche, 2010, p. 6)

A 2017 OECD report goes as far as to argue that "leaving school early should be avoided at all costs" (OECD, 2017, p. 122).

The European Union (EU) has agreed on a "headline target" for education focused on raising attainment, including reducing school drop-out rates below 10\% ("Europe 2020 Headline Indicators," 2017). Given the economic climate, young people are seen by the EU as especially vulnerable, with youth unemployment as well as the proportion of young people not in education, employment, or training having risen since the global financial crisis of 2007-2008.

Similarly, in Australia, a target was set to "achieve a national Year 12 or equivalent attainment rate of 90 per cent by 2015" (CoAG, 2009, p. 4). Year 12 is the final year of senior secondary education. This target is based on an agreement negotiated between the Australian federal, state, and territory governments: the National Partnership on Youth Attainment and Transitions. Consonant with the OECD and EU discourse, the key justification for the target is as follows:

The Parties agree that, especially during the downturn, young people should be supported to attain qualifications in order to be competitive in the labour market both now and when the economy recovers. (CoAG, 2009, p. 7)

However, too often the practices in contemporary schooling contexts have not kept up with this change. In particular, there is extensive evidence that socially and educationally marginalized students are rejected by, or themselves reject, mainstream schooling (McGregor, Mills, te Riele, Baroutsis, \& Hayes, 2017; Skattebol \& Hayes, 2016; Smyth \& Wrigley, 2013). Unsurprisingly, young people from disadvantaged backgrounds are overrepresented among early school leavers. For example, in Australia overall about $26 \%$ of young people do not complete an upper secondary qualification by age 19, but the figure for Indigenous young people it is $46 \%$; for young people from the bottom quintile of socioeconomic status it is almost $40 \%$; and for boys it is $30 \%$ (Lamb, Jackson, Walstab, \& Huo, 2015, p. 42). To better cater to these young people, other forms of educational provision have become a central component of policies for re-engaging young people and enabling their secondary school completion. For example: 
te Riele, K., McGregor, G., Mills, M., Baroutsis, A., \& Hayes, D. (2020, December 17). Learning from alternative schools to enhance school completion. In Oxford Research Encyclopaedia of Education. Oxford University Press. doi: https://doi.org/10.1093/acrefore/9780190264093.013.513

- OECD: The report Off to a Good Start? Jobs for Youth argued that "second-chance schools are necessary to offer young people who have already dropped out a second chance to acquire a useful qualification" (OECD, 2010, p. 84)

- EU: The report Reducing Early School Leaving: Key Messages and Policy Support argues that "second chance schemes as alternative education and training opportunities for young people" are necessary as "compensation measures . . for those young people who have had their education interrupted due to various reasons" (European Commission, 2013, p. 22).

- Australia: As part of the National Partnership on Youth Attainment and Transitions, the Youth Connections program was established, which included providing "disengaged" young people with "access to education or training through an alternative learning facility" (Department of Education, Employment and Workplace Relations [DEEWR], 2010, p. 12).

This article explores the lessons that can be learned from such alternative educational provision for educational reform to improve high school completion. It commences by outlining some of the difficulties associated with the term "alternative schools" as an adequate description of these forms of educational provision.

\section{What's Alternative About Alternative Schools?}

The terms "alternative" and "mainstream" provide useful shorthand descriptions, but we acknowledge that these can be seen as setting up an overly simplistic binary of forms of schooling (Kraftl, 2013). Here, the focus is on the practices of schools that challenge what is commonly available and provide alternative forms of learning for young people who have experienced social and educational marginalization and who are likely to have nowhere else to go to complete high school. These young people are not all the same, but research by the authors of this article shows that many have rejected or chosen to reject what has been previously provided to them. For example, the Albert Park Flexi School produced a video that illustrates the diversity of personal and educational backgrounds and interests that young people bring to that site.

The alternative schools that are the focus of this article are sometimes referred to as "flexible learning programs" (or options) (e.g., McGinty, Wilson, Thomas, \& Lewthwaite, 2018; te Riele, 2014). Others refer to these as "second chance education" (e.g., Day, Mozuraityte, Redgrave, \& McCoshan, 2013; Lim, 2010). In the United States, an early form of such provision was called a "continuation high school" (Kelly, 1993). At times, the broad term "alternative education" is adopted specifically for this particular type of alternative school. For example, the journal Preventing School Failure: Alternative Education for Children and Youth often uses the term "alternative education" to refer to "flexi schools" rather than other forms of alternative school (democratic schools and developmental or holistic schools). In "Alternative Education," Mills and McGregor (2017) elaborate further on these differences in terminology. On the other hand, Vellos and Vadeboncoeur (2013) prefer to reserve the term "alternative education" to approaches based on specific nontraditional philosophies and theories, and use "second chance education" for the programs focused on here, that is, programs that cater to young people for whom mainstream education has not worked well.

The range of terms used can create confusion about this sector of education. For the purposes of this article, the term "unconventional schools" has previously been used (McGregor et al., 2017) to refer to alternative schools that aim to both "do education 
te Riele, K., McGregor, G., Mills, M., Baroutsis, A., \& Hayes, D. (2020, December 17). Learning from alternative schools to enhance school completion. In Oxford Research Encyclopaedia of Education. Oxford University Press.

doi: https://doi.org/10.1093/acrefore/9780190264093.013.513

differently" and offer an inclusive approach to students who have not been well served in their previous schools. For these students, alternative school is not just a second, but often a last chance at gaining a secondary education. There is great diversity within alternative schools, and not all such schools are shining examples of socially just education. Concerns include that alternative schools may prioritize care at the expense of learning and a robust curriculum (Dovemark \& Beach, 2015; Kim \& Taylor, 2008; Thomson \& Pennacchia, 2016). Another is that they may be misused as a as a "stop-gap" measure for "difficult" students or even as a convenient place for traditional schools to "dump" students whom they do not want (Kelly, 1993; Kim \& Taylor, 2008; Mills, Renshaw, \& Zipin, 2013). Even when done well, alternative schools may be perceived as marginal, catering for only a small number of students on the fringes of the education system.

Nevertheless, it is argued here that such schools offer a valuable opportunity to reimagine education and inspire reform that enhances opportunities for high school completion. Importantly, "enhancing" school completion is not merely about "quantity" (reaching a numerical target as per the policies outlined at the start of this article) but even more so about the quality of the educational experience. Both their purpose and their (usually) smaller size mean that alternative schools are well positioned to change default schooling practices (Johnston \& Hayes, 2007) and act as incubators of change (McGregor et al., 2017; Mills \& McGregor, 2017). Such sites are able to demonstrate structural, relational, and curricular changes that enable rather than constrain education and learning. For these reasons, the authors of this article settle on the term "alternative schools," and draw on research conducted with four of these schools in Australia (see McGregor et al., 2017) as well as other Australian and international research.

\section{Structures}

It is well established around the world that children from families who experience poverty and other forms of social exclusion achieve less in school than their more privileged peers (Wilkinson \& Pickett, 2009). The OECD's Programme for International Student Assessment (PISA), which compares how well 15-year-old students in various countries/jurisdictions around the world perform in science, reading, and mathematics, highlights that inequalities are linked to sociocultural background. The 2015 PISA results show that "advantaged students tend to outscore their disadvantaged peers by large margins" (OECD, 2016, p. 40). For example, these results demonstrate that students from socioeconomically disadvantaged backgrounds are almost three times more likely not to attain baseline proficiency in science.

The authors of this article want to reinforce that these differences in achievement cannot be explained by deficit explanations, such as students from disadvantaged backgrounds are less "smart" or less hard-working than their more privileged peers (Smyth \& Wrigley, 2013; Wilkinson \& Pickett, 2009). Decades of research in the sociology of education have shown that structural barriers and hierarchies, as well as inequitable schooling practices and policies, are key drivers of differential outcomes from schooling (Connell, 1993; Teese, 2007). A key OECD report defines equity in education as meaning "that personal or social circumstances ... are not obstacles to achieving educational potential (fairness) and that all individuals reach at least a basic minimum level of skills (inclusion) (OECD, 2012, p. 37). The report goes on to argue that the "lack of inclusion and fairness fuels school failure, of which dropout is the most visible manifestation." 


\section{The Cost of Education}

The financial cost of secondary education can be a significant barrier to school completion. Even when government-provided schooling is officially free, students and their families face many costs associated with staying in school, such as textbooks, materials for elective subjects, transport, school uniforms, and "voluntary" school fees. For example, an Australian study (Bond \& Horn, 2009, p. 26) estimated the annual cost of full participation for a secondary school student to be almost AUD\$4,000 (about US\$3,000, GB£2,000 or EUR€2,500). An Australian charity found that almost 40\% of their emergency relief clients could not afford textbooks or school activities and outings (Salvation Army, 2013). A student reflected on the expense of elective subjects:

You have to do six electives a year, but you didn't know there was a catch - each course costs $\$ 200$. . . Just to do art it was $\$ 200$ and you have to do it so you were paying $\$ 800$ to $\$ 1,000 \ldots$ and some courses are more expensive, like the computer courses, and both my brothers are really into them. (Cited in Myconos, 2011, p. 13)

Other Australian research demonstrated how young people pretended not to be interested in excursions and "opting for affordable subjects rather than those that aligned with their interests and aspirations" (Skattebol, Saunders, Redmond, Bedford, \& Cass, 2012, p. 121) in order to maintain their own and their family's dignity. As a result, their capacity to reach their educational potential is limited.

By contrast, many alternative schools aim to make learning activities and materials freely available. Often, they are astute in funding this, for example, by seeking the support of community groups such as Rotary, applying for (and winning) prizes for excellence, cultivating committed volunteers, and sourcing materials from recycling shops and refuse yards (McGregor et al., 2017; te Riele, 2014).

Beyond costs directly associated with learning, poverty affects young people's capacity to engage with schooling more broadly. For example, a student who tried to access a vocational program explained that transport to the course "was costing me $\$ 50$ a week, and there's food and stuff as well, so it was just too much" (cited in Myconos, 2011, p. 30). Similarly, a teacher explained the priority the school placed on meeting students' basic needs:

They know that our school is a place where they can come and get fed, you know if they're not too embarrassed they can have a shower, they can brush their teeth, they can get a new set of clothes. (McGregor et al., 2017, p. 74)

\section{Basic Needs}

In some countries, such as the United Kingdom and United States, free or reduced-price school meals are available for students from economically disadvantaged backgrounds. This helps address a core basic need and enables the inclusion of students from backgrounds of poverty. However, recent reports from aid agencies show that these programs are struggling to meet the need. For example, workers from the "No Kid Hungry" campaign claim, "One in five children in the United States live in food insecure households, which means they lack consistent access to enough food" (Seaton, 2017, n.p.). In other countries, access to affordable food is also a concern for students. In Australia, it is estimated that every school day, three students in every class arrive at school hungry or without having eaten breakfast (Foodbank Australia, 2015, p. 4). In a recent report, the CEO of Foodbank Australia said that 
in Queensland, young people in areas of Brisbane where there are high levels of disadvantage were being kept home from school "because their parents had nothing left to pack for their lunches" (Hall, 2018, n.p.). This has a significant negative impact not only on students' wellbeing but on their capacity to learn (Dimbleby \& Vincent, 2013). Drawing on Maslow's (1971) hierarchy of needs, a teacher argued that people cannot expect students to do "higher order thinking" if they are hungry (McGregor et al., 2017 p. 74).

Providing food is a simple but vital intervention (Belot \& James, 2009) that is common in alternative schools in Australia (Mills \& McGregor, 2014; te Riele, 2014), with some students indicating that if not for these meals, they would have gone hungry.

Such practical support by alternative schools extends to other basic needs, such as transport, clothing, and access to services for housing, legal aid, and physical and mental health (McGregor et al., 2017; Myconos, 2018; te Riele, 2014). Alternative schools recognize this work is crucial as a "necessary pre-condition for educational engagement and progress" (Myconos, 2018, p. 38). As staff from one school put it, it is about "clearing the path for learning" (McGregor et al., 2017, p. 73). Often this comes at a significant financial cost to the school:

It's hard to run these programs financially. ... even when it's at full tilt, you're still not receiving the same kind of funding a secondary school receives, while working with people who need much higher levels of resources. (Teacher cited in te Riele, 2014, p. 67)

The implication is that not only can regular schools learn from the ways in which alternative schools address financial barriers to school completion, but they also may be better funded to do so. Within the mainstream system, there is evidence of attempts to provide similar structural support through "full-service schools" (e.g., Black, Lemon, \& Walsh, 2010; Quinn \& Dryfoos, 2009; Wilkin, White, \& Kinder, 2003). There is variety in the "extra services" provided through such models, addressing material needs, medical and psychological services, or learning supports. Some full-service schools resemble the alternative schools ed here, in that they aim to reconceptualize schooling through the provision of a different way of operating. Others are based on an assumption that it is the student and/or their circumstances that need "fixing" through additional services as a "bolt-on" to their standard ways of operating. As the authors of this article have argued elsewhere:

Schools do need to change, and we would suggest that whilst the provision of extended services is not enough, we also contend that it is necessary as part of that change.

(McGregor et al., 2017, p. 73)

\section{Relations}

Supportive relationships are significant in enhancing the quality of young people's educational experiences and outcomes (Bingham \& Sidorkin, 2004; Noddings, 1984). Unfortunately, negative relations with staff and peers are a major factor in early school leaving (Archambault, Janosz, Fallu, \& Pagani, 2009).

\section{Belonging}

A sense of belonging is a powerful human need that is fundamental to people's well-being (Maslow, 1971). In an educational context, feeling connected has positive impacts on students' affective well-being as well as on their academic outcomes (Allen \& Bowles, 2012; 
te Riele, K., McGregor, G., Mills, M., Baroutsis, A., \& Hayes, D. (2020, December 17). Learning from alternative schools to enhance school completion. In Oxford Research Encyclopaedia of Education. Oxford University Press. doi: https://doi.org/10.1093/acrefore/9780190264093.013.513

Bergin, 1999). Schools offer an opportunity to facilitate belonging; however, not all students experience this aspect of schooling. Some young people feel isolated and unwanted in school (Vadeboncoeur \& Vellos, 2016). The detrimental effects of being an outsider, or "other," in school serve to highlight the value of belonging (Allen \& Bowles, 2012).

Students may feel marginalized because of their racial background. Loutzenheiser (2002) provides the vivid example of a young Black woman in the United States who was made to feel as "Other" during her enrolment interview when staff pointed out there were few other Black students in the school: "she left the first meeting at the school where she was hoping to start over, feeling different and unwelcome" (p. 447). In the Australian context, Indigenous students often feel teachers are stricter with and less supportive of them than with their European background peers. A student indicated: "I am half Aboriginal, so teachers were always very judgmental towards me" (McGregor et al., 2017, p. 49). She gave as an example that when everyone in a class was talking and she and her Aboriginal friends would be "talking amongst ourselves, doing our work," the teacher would only "yell and scream at us, and let everyone else continue to do it." The history of discrimination against racial minorities in many countries around the world makes it particularly important to redress such experiences.

Mental illness, being in out-of-home care (in the care of the state), and teenage pregnancy and parenting can also attract negative stereotyping (Evans, Meyer, Pinney, \& Robinson, 2009; Vincent, 2012). The experience of young mothers is explored in a video about a program called 'Skills for Tomorrow', which was set up specifically as an alternative education option for young mums.

Vadeboncoeur and Vellos (2016) report three ways in which alternative education programs develop positive student-teacher relationships that support belonging:

(1) Being seen: students feel that staff recognize ("see") them as individual people.

(2) Recognizing the capacity to grow: both student and staff are able to develop and change, and recognize this quality in each other.

(3) Co-creating social futures: learning from each other, over time teachers and students together create new and different possibilities.

Summing this up as a "moral imagination," Vadeboncoeur and Vellos (2016, pp. 320-321) suggest that an implication for school reform, therefore, is to act on a shared "commitment to reimagining schooled practices, such as student-teacher relationships, with young people as our guides."

As part of its international research program with 15-year-old students (PISA), the OECD examined students' sense of belonging:

Students tend to thrive when they form positive relationships with peers, feel part of a social group, and feel at ease at school. A lack of connectedness can adversely affect students' perceptions of themselves, their satisfaction with life, and their willingness to learn and to put effort into their studies. ... In some countries sizable minorities of students do not have positive relationships with their peers at school, do not feel connected with their school, and are not happy or satisfied with school. (OECD, 2013, p. 51)

For example, the countries or locations where fewer than $80 \%$ of surveyed students agreed they felt like they belonged at school included Australia, New Zealand, Canada, Tunisia, Korea, Hong Kong, Macau, and several European countries (OECD, 2013, p. 251). 
te Riele, K., McGregor, G., Mills, M., Baroutsis, A., \& Hayes, D. (2020, December 17). Learning from alternative schools to enhance school completion. In Oxford Research Encyclopaedia of Education. Oxford University Press.

doi: https://doi.org/10.1093/acrefore/9780190264093.013.513

Young people's sense of belonging at school can be undermined by practices that they find intrusive and disrespectful. Their attempts to keep aspects of their lives private are sometimes threatened when their problems and personal difficulties are widely known. The authors of this article have reported elsewhere how young people, when reflecting on their prior experiences at a mainstream school, "objected to the stares and 'funny' behaviour associated with people knowing their business and feared that this made them vulnerable to being stigmatized due to their social and economic location" (Hayes \& Skattebol, 2014, p. 521). They emphasized how important it was to them that their teacher respected their need for privacy.

Belonging is also tied to addressing broader issues of discrimination based on, for example, race or sexuality. As has often been identified, those from marginalized backgrounds regularly experience school as unwelcoming, in terms of, for example, the ways in which they are treated by staff as deficit in some way or by a lack of representation in the curriculum. Hence, students from such backgrounds often find themselves in alternative provision. In many alternative schools, there has been an attempt to ensure that "culture" is recognized and valued. For example, in one alternative school in Australia with a very high population of Indigenous girls, local elders from the Aboriginal community help to shape the curriculum, school governance, and everyday rhythms of the school, to ensure that the girls see it as their school (Mills \& McGregor, 2014).

\section{Authoritarian Versus Democratic Approaches}

A common critique of mainstream schooling, from young people and from research, is in relation to authoritarian approaches by staff toward students. The teacher-student relationship is inherently unequal, and school organization is fundamentally hierarchical. The way in which school rules and regulations are applied has a major impact on the relationship between teachers and students (Smyth, Down, \& McInerney, 2010; te Riele, 2012). Too often, classroom management (creating a classroom environment that fosters learning) is narrowly and counterproductively interpreted as behavior management (eliminating "bad" student behavior).

In the context of young people's quest for establishing their own identity and independence, it is not surprising that young people find requirements to fit in with a rigid image of the "good student" oppressive (McLaren, 2016); nor that they are highly sensitive to disciplinary approaches they perceive as unfair (Myconos, 2011). In countries where school uniform is common, such as Australia, a school's insistence on strict adherence to the uniform can easily create tensions. Young people often object to getting reprimanded for wearing the wrong-colored socks or the wrong type of shoes, and resent not being able to express their own identity (e.g., McGregor et al., 2017, p. 53). This has been expressed in research countless times; for example, one student noted the importance of being a "free spirit" and being able to wear different clothes, which was not tolerated at her previous, mainstream school. She explained:

I'm not really into having a set way of looking and being, because I don't believe that a school should teach you how to look or how to be; they're just there to teach you how to do maths, English and the subjects you need in order to make it; the rest of it is your choice in life. (Mills, McGregor, Hayes, \& te Riele, 2015, p. 160).

Although this student's focus on only core subjects may be a somewhat narrow interpretation of the purpose of schooling, the above distinction between how a student looks and his or her 
te Riele, K., McGregor, G., Mills, M., Baroutsis, A., \& Hayes, D. (2020, December 17). Learning from alternative schools to enhance school completion. In Oxford Research Encyclopaedia of Education. Oxford University Press.

doi: https://doi.org/10.1093/acrefore/9780190264093.013.513

learning is well made. When enforcing school rules and regulations is emphasized in secondary schools, opportunities for learning are interrupted and undermined. Zero-tolerance school discipline policies have been shown to be ineffective and even discriminatory (in relation to race and poverty), and the use of punitive discipline measures actively creates barriers to education (Skiba, 2014). This is especially the case when students are explicitly removed from the classroom, through temporary or permanent exclusion.

In a context of education policies across many OECD countries that rank schools based on student results on standardized tests and that emphasize parental school choice, schools may well be tempted to exclude students who are naughty, different, need extra help, or are in some other way "problematic." Such practices may be enabled by official guidelines in education jurisdictions. For example, in several Australian states, the power of principals (heads) in government schools to expel (i.e., permanently exclude children from a school) has increased. The basis for permanent exclusion from a school is often open to interpretation based on broad constructions of behaviors, for example: "conduct . . . that is prejudicial to the good order and management of the school or state schools" (Education Queensland, 2006). Based on an analysis of official school expulsion reports, the Victorian Ombudsman (2017, p. 28) found that in over $40 \%$ of cases, the student's behavior was not so serious as to warrant expulsion. An example is provided here:

A secondary school student was expelled after repeatedly failing to comply with staff instructions. This included using her mobile phone in class; not bringing appropriate equipment to class; not attempting or completing any work in class; and using aggressive and offensive language towards staff and other students. (Victorian Ombudsman, 2017, p. 28)

Undoubtedly such behavior is frustrating for teachers. However, exclusion from school is an extreme measure with significant negative impacts on students (Losen \& Gillespie, 2012). Exclusion from school is a significant social justice concern and, in many countries, also a legal concern when legislation mandates compulsory enrollment in school up to a particular age. Upon trying to enroll in a new school, students may be told that the school is "full" or would not suit them. Alternative schools often are a "last chance" for these students. Not only do the kinds of alternative schools discussed here enroll students who have been rejected elsewhere, they usually do not use temporary or permanent expulsion themselves. Teachers at some of the schools explained that although young people were sometimes asked to go home as a "circuit breaker," they were always welcomed back with the explicit or implicit message that "we will not give up on you" (McGregor et al., 2017, pp. 86-87). More importantly, alternative schools also often actively pursue a more democratic approach to staff-student relations. This revolves around student voice and student choice.

Opportunities for student voice and student particpation can occur on several levels, some more superficial and others more deeply equitable and democratic (Hart, 1997; Mitra, 2006). A deeper level of voice is associated with young people and adults working together collaboratively to engage in problem-solving and decision-making related to issues that are important to young people (Fielding, 2001) and with situations where leadership capacities are developed in young people.

Research shows that children and young people in alternative schools mostly felt that staff listened to them and took their views into account (Baroutsis, McGregor, \& Mills, 2016; McGregor et al., 2017). This may be fostered intentionally but somewhat informally through a school culture where staff take a collaborative approach. More formally, this is enabled by structures that promote partnerships between staff and students, as well as opportunities for student leadership and decision-making. At an individual student level, an example is the 
timetabling of occasions to develop and revisit personal learning plans. For a whole class or whole school, meetings where students as well as staff can raise topics for discussion foster a democratic approach. For example, one school began each day with a "community forum" that was student led and provided opportunities for student leadership and collaborative decision-making that developed the partnerships within the school (Baroutsis, Mills, McGregor, te Riele, \& Hayes, 2016; McGregor et al., 2017). Such a community forum is intended as a practice that honors young people's voices. It is an opportunity for

students and staff to sit down together as partners, reflect on their work and aspirations, raise matters of individual and communal significance, celebrate achievements, hold each other to account, and decide on what to do next. (Fielding, 2013, p. 124)

In the example of the community forum, young people and staff sat interspersed in a large circle in an open space, without assigned seats for staff or students. Each day, a different young person led the community forum. The forum was generally structured into three parts: a discussion of issues that related to local and wider community news and school announcements; a check-in where each member of the community voiced their readiness (or otherwise) for the day's learning; and a sign-up process that incorporated decision-making and informed choice regarding the day's learning sessions. This kind of forum runs counter to the usual more hierarchical approaches in schools. It offers students opportunities to practice active citizenship — what Biesta (2001, p. 747) refers to as "educating for democracy, through democracy." It also creates a space for students to exercise choice.

Choice is strongly related to what and how to learn so that learning is meaningful. A student suggested: "Instead of being told what you have to do, it's more, well, they care about your interests more" (McGregor et al., 2017, p. 111). Personal learning plans are a powerful tool for empowering student choice in relation to the curriculum. Being able to contribute to their own goals and build on their own interests enhances student motivation. When students have shared responsibility for their own learning, this can also improve their academic achievement (Lamb \& Rice, 2008).

\section{Curriculum}

Finally, the school curriculum is essential for facilitating an education that is meaningful and authentic and builds the capabilities young people need in the 21 st century. In many instances, however, the curriculum may work against learning. A common way in which young people express this is by saying they are "bored." As Evans et al. (2009, p. 22) explain, "Boredom was high on the list of reasons that prevented survey respondents from doing well at school." Although authorities (curriculum boards and politicians as well as school leaders and teachers) perceive a worthwhile education in terms of productivity and economic prosperity, and expect students to accept the official curriculum as given, in the secondary years of schooling young people are more likely to want to have a say in both what to learn and how to learn it.

An example is a video produced by students from the Melbourne Academy. Starting with the interest of many students in hip-hop and rap music, the staff developed a sequence of learning that connected these interests and students' own experiences of street life with the social history of those music genres. In collaboration with local musicians, the students produced this video, titled "Straight Outta North Fitz," inspired by a hip-hop song called "Straight Outta Compton." Not only was the work to produce the video mapped against the formal curriculum, it was included in the youth program of a prestigious local film festival. 
te Riele, K., McGregor, G., Mills, M., Baroutsis, A., \& Hayes, D. (2020, December 17). Learning from alternative schools to enhance school completion. In Oxford Research Encyclopaedia of Education. Oxford University Press.

doi: https://doi.org/10.1093/acrefore/9780190264093.013.513

As the video highlights, for many young people the personal and social meaning of their learning is paramount. This may well be connected with a vocational focus, but within the scope of building a good life for themselves and in their community rather than as human capital for the nation's international economic competitiveness.

\section{Personalized Learning}

Despite broad recognition of the importance of differentiated instruction (Subban, 2006; Tomlinson, 2014), individualization of the curriculum can be difficult for teachers to implement. The age-grade system of organizing schools that is common across the world means teachers may find students in their class who are around the same age but whose knowledge and skill in a particular subject may well lie several grade levels apart. As teachers have been known to suggest, the curriculum content in traditional secondary schools tends to be "directed towards the middle level" (McGregor et al., 2017, p. 61). As a result, "the lower kids were totally lost," and in addition "students that are really gifted, they generally missed out, and then [there is] the possibility of behavioural problems and boredom" (McGregor et al., 2017). As an example of the latter, another young person, in a study on early school leaving (Taylor \& Nelms, 2008, p. 14) said, "It was just that the classes weren't challenging enough for me and I tended to get real bored."

By contrast, the Big Picture Learning (BPL) model developed in the United States offers an example of a personalized learning approach. BPL is based on the idea of "one student at a time" where "the entire learning experience is personalized to each student's interests, talents and needs" (Big Picture Learning, n.d., p. 1). This approach highlights that curriculum and pedagogy are closely connected, and reform in one often goes alongside reform in the other. Littky and Grabelle (2004) explain that genuine personalization in BPL applies to learning activity within schools (curriculum and assessment) as well as to structures such as the way students are grouped and their timetables. In particular, they emphasize that enforcing a homogenous curriculum on all students in a certain class or grade is counterproductive for learning.

Although such a "child-centered" approach to education has been advocated for many decades, it is still not widespread. Now that standardized and standards-based approaches to education have become entrenched, it is perhaps more necessary to offer examples (such as from alternative education) to demonstrate both that and how personalized approaches to curriculum work, in order to be part of broader school reform. Within alternative schools a commitment to building the educational provision around the student is common, by treating each student as an individual and using personalized learning plans to create curriculum. This does not mean students do not engage in shared activities, but rather that those experiences are connected back to their own learning goals. Personalized (or individual) learning plans (PLPs) are commonly used. Such plans have been advocated for a more inclusive approach to education, especially when they incorporate not only learning needs but also achievements, and when they are regularly revisited and updates (Morton \& Guerin, 2017).

In mainstream schools, the development and use of learning plans is commonly a requirement for students with registered disabilities. However, in many alternative schools the practice is that all students will have their own PLP. These provide a foundation for planning student learning by enabling staff to understand each student's interests and learning styles, and offer a process for developing students' own learning goals. For example, at one school, the PLP led to students having their own folder of curriculum materials to work through at their own pace (McGregor, Mills, te Riele, \& Hayes, 2015). The content of this 
te Riele, K., McGregor, G., Mills, M., Baroutsis, A., \& Hayes, D. (2020, December 17). Learning from alternative schools to enhance school completion. In Oxford Research Encyclopaedia of Education. Oxford University Press.

doi: https://doi.org/10.1093/acrefore/9780190264093.013.513

folder may vary in terms of the topics included and/or in terms of the level at which each student will tackle a topic. As a student, explained:

I'm just doing my own work at the moment, because I have my folder, everybody in the class has their own folder where there's a set of works in there that they have to complete. Like, some English stuff and some maths stuff and when they're done, like, it gets ticked off. (McGregor et al., 2015, p. 614)

Rather than imposing a curriculum-based timetable on students, staff in alternative schools use their expertise to map the PLP and the activities undertaken against the official curriculum. As a staff member in an alternative school stated: "Everything we do with the kids, we fit into the curriculum" (te Riele, 2014, p. 56).

\section{Interest and Relevance}

Within the psychology of education, a key research field has focused on student interest and motivation. Overwhelmingly, this research shows that when a student is interested in the activities provided through the school curriculum, his or her educational engagement and academic achievement are enhanced (Bergin, 1999; Rotgans \& Schmidt, 2012). When content fails to reflect students' lives, it reduces interest. Unfortunately, "goal relevance is particularly problematic in school, because few of the subjects that students study or the tasks they are asked to do are clearly relevant to students' current concerns and goals" (Bergin, 1999, p. 91). As a young Australian woman in one study put it: "Schooling has got absolutely nothing to do with my life" (McInerney, 2009, p. 30). Bridgeland, Dilulio, and Morison (2006, p. 12) argue that, in U.S. high schools, classwork "needs to make some connection to students' interests and what they find relevant." More relevant topics suggested by students may include sex and relationship education, as well as content dealing with trauma, racism, and homophobia (Evans et al., 2009; Loutzenheiser, 2002).

Alternative schools invest considerable effort into developing curriculum that is relevant and meaningful for young people (Hayes, 2012; McGregor et al., 2015; te Riele, 2014). Often, this is about drawing on "real-life" situations that students are experiencing, for example "buying a car is one of the maths assignments. Figuring out how much paint you're going to need to paint a room in a house" (te Riele, 2014, p. 54). Service learning can also connect with students' lives. Many students in one of the programs in our research had experiences of homelessness, which led to a particular project being implemented:

We are going to aim to make some swags with an industrial sewing machine, roll them with toothpaste, toothbrushes, towel, whatever we find, soap, and then we will give them to one of our local homeless shelters for the winter. (McGregor et al., 2015, p. 618)

Although some research has expressed concern about the quality of the curriculum in alternative schools (Kim \& Taylor, 2008), developing interesting and relevant curriculum need not automatically mean a lowering of standards. The International Baccalaureate (IB) is an example of an education program that incorporates significant scope for students to choose interest-based topics and activities and is also widely recognized as being rigorous and of high quality (Tarc, 2009). IB schools tend to have elite status, in contrast to the alternative schools discussed here. Nevertheless, the emphasis on high expectations and challenging work, based on, for example, the Big Picture Learning model used in one of our schools is important: 
te Riele, K., McGregor, G., Mills, M., Baroutsis, A., \& Hayes, D. (2020, December 17). Learning from alternative schools to enhance school completion. In Oxford Research Encyclopaedia of Education. Oxford University Press.

The Year 12s [final year of upper secondary education in Australia] have finished what we call an investigative report. Big Picture has different learning goals. There's empirical learning goals, quantitative/social reasoning. So they had to design a survey on a social issue, interview 20 mainstream students, interview 20 Big Picture students, collate their results, graph it, analyse it, and hand it back in to me ... And they were fascinated by what other people were doing and, you know, they were doing things on drugs and the age of consent and all sorts of things. Each had their own little niche and they were so proud of it ... At the end of each semester we have an exhibition, parents coming in. So, they will be able to go through their portfolio and be explicit about what they have done, what they learnt. (McGregor et al., 2015, p. 618)

Reinforcing this approach, research has highlighted that explicit teaching of metacognitive strategies is most useful when accompanied by a focus on substantive content, including "links to students' lives and worlds outside of school" (Luke, Woods, \& Dooley, 2011, p. 162).

Young people who have been disengaged from school also commonly indicate they would prefer more practical and hands-on work (Bridgeland et al., 2006; Evans et al., 2009; McInerney, 2009). In the words of one young person: "There were a lot of worksheets. I would have preferred more practical stuff" (Evans et al., 2009, p. 19). These young people wanted work that provided life skills such as financial literacy and skills that were relevant for work. Bridgeland et al. (2006, p. 12) found that $80 \%$ of their U.S. sample of self-reported "dropouts" said that more "real-world learning" would have increased the likelihood of them completing high school.

One response by alternative schools is to offer a range of practical short courses such as first aid, workplace health and safety for the construction industry, barista training, and responsible service of alcohol. These courses have the added advantage of enabling students to attain part-time work that provides an income while they are studying. Alternative schools may also offer explicit advice about résumé writing or job interview strategies, in the recognition that students from disadvantaged backgrounds may not have access to the social and cultural capital (Bourdieu, 1984) that provides such knowledge outside of school for students from more privileged backgrounds. Additionally, vocational subjects and work placements tend to be purposefully linked to students' interests and thus made more meaningful. This approach is illustrated well through a video about an alternative program called Wirreanda Adaptive Vocational Education.

Importantly, teachers have indicated that the focus is on supporting young people to achieve their own career goals, whatever they may be: "If you want to go and become a bricklayer, we're going to help you get there. If you want to get into university, we're going to help you get there" (te Riele, 2014, p. 49).

Finally, much attention has been given at national and international levels to the need for curriculum to be updated to reflect the "21st-century capabilities" young people require. Although various agencies have their own specific lists (e.g., Care \& Luo, 2016; European Commission, 2018), typical of this body of work is that it transcends traditional academic subjects or disciplines and instead names capabilities to do with innovation and problemsolving, communication and collaboration, and social responsibility and citizenship. Attention to such cross-cutting competencies is often embedded in the project-based approach common in alternative schools and also responds to the call for relevance from young people. 


\section{Conclusion}

This article has indicated some of the lessons that mainstream schools can learn from alternative schools to enhance school completion. It has highlighted some of the ways in which alternative schools have tackled this issue through addressing the (often interrelated) structural barriers that inhibit attendance at school. These include, for instance, poverty, homelessness, and transport difficulties, as well as parenting and other caring responsibilities. Strategies have involved providing food, public transport travel cards, crèches, and various social work services. Many alternative schools have also sought to ensure that students develop a sense of belonging in their school. Developing positive relationships between staff and students, students and students, and staff and staff has been central to this. In some instances there have been structural responses to ensure that student voice is heard, for example, through community meetings, in other instances it is through creating sets of personal dynamics that avoid authoritarian, oppressive or aggressive engagements between different members of the a school community. Underpinning these strategies, both structural and relations, is making the school a place where students are both able and want to attend.

We acknowledge that school completion can have many benefits but what occurs within the period of time a student is in school is also of the utmost importance. Completion is important but it is the social and academic benefits provided by being at school that ensure the current and future success of students. To this end, appropriate and meaningful curricula are essential to ensuring that young people are engaged in education. Here we have identified some of the ways that some alternative schools seek to provide their students with tailor made curricula, that builds up on their interests and has meaning for them. At the same time, these need to be intellectually rigors so that "second chance" does not become "second best" and so that students' opportunities for academic success are enhanced.

In this chapter, we have not focused on the issue of quality. It is one that has to be addressed in relation to alternative schooling of the type discussed in this chapter. In different locations there have been concerns about the ways in which these schools can act as "dumping grounds" for those unwanted by the mainstream (see, e.g., Dovemark \& Beach, 2015; Kelly, 1993; Kim \& Taylor, 2008; Mills et al., 2013; Ofsted, 2016; Thomson \& Pennacchia, 2015), especially given the performative pressures on schools which have been associated with increased (and sometimes illegal) exclusions (see, e.g., Office of the Children's Commissioner, 2013). Instead, our purpose here has been to identify those practices which keep young people who are in danger of missing out on education in meaningful forms of schooling. We are aware that there are some excellent mainstream schools which already serve such students well. However, the widespread, and increasing, use of alternative schooling as a site for those not served well by contemporary schooling would suggest that a lot more could be done at a system level.

\section{References}

Archambault, I., Janosz, M., Fallu, J. S., \& Pagani, L. S. (2009). Student engagement and its relationship with early high school dropout. Journal of Adolescence, 32(3), 651-670.

Baroutsis, A., McGregor, G., \& Mills, M. (2016). Pedagogic voice: Student voice in teaching and engagement pedagogies. Pedagogy, Culture and Society, 24(1), 123-140.

Baroutsis, A., Mills, M., McGregor, G., te Riele, K., \& Hayes, D. (2015). Student voice and the community forum: Finding ways of "being heard" at an alternative school for disenfranchised young people. British Educational Research Journal, 42(3), 438-453. 
te Riele, K., McGregor, G., Mills, M., Baroutsis, A., \& Hayes, D. (2020, December 17). Learning from alternative schools to enhance school completion. In Oxford Research Encyclopaedia of Education. Oxford University Press.

doi: https://doi.org/10.1093/acrefore/9780190264093.013.513

Belot, M., \& James, J. (2009). Healthy school meals and educational outcomes, Journal of Health Economics, 30(3), 489-504.

Bergin, D. (1999). Influences on classroom interest. Educational Psychologist, 34(2), 87-98.

Biesta, G. (2001). Education and the democratic person: Towards a political conception of democratic education. Teachers College Record, 109(3), 740-769.

Big Picture Learning. (n.d.). www.bigpicture.org/apps/pages/index.jsp?uREC_ID $=389353 \&$ type $=\mathrm{d} \& \mathrm{pREC} \_\mathrm{ID}=90$ 2235

Bingham, C., \& Sidorkin, A. (Eds.). (2004). No education without relation. New York, NY: Peter Lang.

Black, R., Lemon, B., \& Walsh, L. (2010). Literature review and background research for the National Collaboration Project: Extended Service School Model, Final report. Melbourne, VIC: The Foundation for Young Australians.

Bond, S., \& Horn, M. (2009). The cost of a free education: Cost as a barrier to Australian public education. Melbourne, VIC: Brotherhood of St Laurence.

Bourdieu, P. (1984). Distinction. London, UK: Routledge.

Bridgeland, J., Dilulio, J., \& Morison, K. (2006). The silent epidemic: Perspectives of high school dropouts. Washington, DC: Civic Enterprises.

Care, E., \& Luo, R. (2016). Assessment of transversal competencies: Policy and practice in the Asia-Pacific region. Paris, France: UNESCO.

Council of Australian Governments (CoAG). (2009). National partnership agreement on youth attainment and transitions. Council of Australian Governments. Canberra, Australia: AGPS.

Connell, R. W. (1993). Schools and social justice. Philadelphia, PA: Temple University Press.

Day, L., Mozuraityte, N., Redgrave, K., \& McCoshan, A. (2013). Preventing early school leaving in Europe: Lessons learned from second chance education. Luxembourg: Publications Office of the European Union.

Department of Education, Employment and Workplace Relations (DEEWR). (2010). Youth connections: Program guidelines. Canberra, Australia: Government of Australia, Department of Education, Employment and Workplace Relations.

Dimbleby, H., \& Vincent, J. (2013). The school food plan. Sheffield, UK: Children's Food Trust.

Dovemark, M., \& Beach, D. (2015). Academic work on a back-burner: Habituating students in the upper-secondary school towards marginality and a life in the precariat. International Journal of Inclusive Education, 19(6), 583-594.

Education Queensland. (2006). Grounds for school disciplinary absence. Brisbane, QLD: State of Queensland Department of Education and Training.

Europe 2020 headline indicators (2017). Eurostat: Statistics Explained.

ec.europa.eu/eurostat/statisticsexplained/index.php/Europe_2020_headline_indicators.

European Commission. (2013). Reducing éarly school leaving: Key messages and policy support. Brussels, Belgium: European Commission.

European Commission. (2018). Key competences for lifelong learning a European reference framework: Annex to the proposal for a council recommendation on key competences for lifelong learning.

Evans, J., Meyer, D., Pinney, A., \& Robinson, B. (2009). Second chances: Re-engaging young people in education and training. Essex, UK: Barnardos.

Fielding, M. (2001). Students as radical agents of change. Journal of Educational Change, 2(2), 123-141. 
te Riele, K., McGregor, G., Mills, M., Baroutsis, A., \& Hayes, D. (2020, December 17). Learning from alternative schools to enhance school completion. In Oxford Research Encyclopaedia of Education. Oxford University Press.

doi: https://doi.org/10.1093/acrefore/9780190264093.013.513

Fielding, M. (2013). Whole school meetings and the development of radical democratic community. Studies in Philosophy and Education, 32(2), 123-140.

Foodbank Australia. (2015). Hunger in the classroom: Foodbank report 2015 www.foodbank.org.au/wp-content/uploads/2019/05/Foodbank-Hunger-in-theClassroom-Report-May-2015.pdf.

Hall, P. (2018, March 3). Children going to school hungry. The Gympie Times. www.pressreader.com/australia/the-gympie-times/20180303/281651075606078.

Hart, R. (1997). Children's participation: The theory and practice of involving young citizens in community development and environmental care. London, UK: UNICEF.

Hayes, D. (2012). Re-engaging marginalised young people in learning: The contribution of informal learning and community-based collaborations. Journal of Education Policy, 27(5), 641-653.

Hayes, D., \& Skattebol, J. (2014). Education and the politics of belonging. In J. Wyn \& H. Cahill (Eds.), Handbook of children \& youth studies (pp. 517-528). Singapore: Springer Science + Business Media.

Johnston, K., \& Hayes, D. (2007). Supporting student success at school through teacher professional learning: The pedagogy of disrupting the default modes of schooling. International Journal of Inclusive Education, 11(3), 371-381.

Kelly, D. (1993). Last change high: How girls and boys drop in and out of alternative schools. New Haven, CT: Yale University Press.

Kim, J. H., \& Taylor, K. (2008). Rethinking alternative education to break the cycle of educational inequality and inequity. Journal of Educational Research, 101(4), 207219.

Kraftl, P. (2013). Geographies of alternative education: Diverse learning spaces for children and young people. Bristol, UK: Policy Press.

Lamb, S., Jackson, J., Walstab, A., \& Huo, S. (2015). Educational opportunity in Australia 2015: Who succeeds and who misses out. Centre for International Research on Education Systems, Victoria University, for the Mitchell Institute. Melbourne, VIC: Mitchell Institute.

Lamb, S., \& Rice, S. (2008). Effective intervention strategies for students at risk of early leaving: Discussion paper. Melbourne, VIC: Centre for Post-compulsory Education and Lifelong Learning, The University of Melbourne.

Lim, D. (2010). Provision of second-chance education: The Hong Kong experience. Education + Training, 52(4), 304-320.

Littky, D., \& Grabelle, S. (2004). The big picture: Education is everyone's business. Alexandria, VA: Association for Supervision and Communications Development.

Losen, D. J., \& Gillespie, J. (2012). Opportunities suspended: The disparate impact of disciplinary exclusion from school. Los Angeles, CA: Civil Rights Project/Proyecto Derechos Civiles.

Loutzenheiser, L. (2002). Being seen and heard: Listening to young women in alternative schools. Anthropology \& Education Quarterly, 33(4), 441-464.

Luke, A., Woods, A., \& Dooley, K. (2011). Comprehension as social and intellectual practice: Rebuilding curriculum in low socioeconomic and cultural minority schools. Theory Into Practice, 50(2), 157-164.

Lyche, C. (2010). Taking on the Completion Challenge: A literature review on policies to prevent dropout and early school leaving. OECD Education Working Papers, No. 53. Paris, France: OECD.

Maslow, A. H. (1971). The farther reaches of human nature. Oxford, UK: Viking.

McGinty, S., Wilson, K., Thomas, J., \& Lewthwaite, B. (Eds.). (2017). Gauging the value of education for disenfranchised youth. Leiden, Netherlands: Brill Sense. 
te Riele, K., McGregor, G., Mills, M., Baroutsis, A., \& Hayes, D. (2020, December 17). Learning from alternative schools to enhance school completion. In Oxford Research Encyclopaedia of Education. Oxford University Press.

McGregor, G., Mills, M., te Riele, K., Baroutsis, A., \& Hayes, D. (2017). Re-imagining schooling for education: Socially just alternatives. London, UK: Palgrave Macmillan.

McGregor, G., Mills, M., te Riele, K., \& Hayes, D. (2015). Excluded from school: Getting a second chance at a "meaningful" education. International Journal of Inclusive Education, 19(6), 608-625.

McInerney, P. (2009). Toward a critical pedagogy of engagement for alienated youth: Insights from Freire and school-based research. Critical Studies in Education, 50(1), $23-35$.

McLaren, P. (2016). Life in schools. An introduction to critical pedagogy in the foundations of education (6th ed.). New York, NY: Routledge.

Mills, M., \& McGregor, G. (2017). Alternative education In G. W. Noblit (Ed.), The Oxford research encyclopedia of education. Oxford, UK: Oxford University Press.

Mills, M., Renshaw, P., \& Zipin, L. (2013). Alternative education provision: A dumping ground for "wasted lives" or a challenge to the mainstream? Social Alternatives, $32(2), 13-18$.

Mitra, D. L. (2006). Increasing student voice and moving towards youth leadership. The Prevention Researcher, 13(1), 7-10.

Morton, M., \& Guerin, A. (2017). Sociocultural perspectives on curriculum, pedagogy, and assessment to support inclusive education. In G. W. Noblit (Ed.), The Oxford encyclopedia of education. Oxford, UK: Oxford University of Press.

Myconos, G. (2011). A path to reengagement: Evaluating the first year of a community VCAL education program for young people. Fitzroy, VIC: Brotherhood of St Laurence.

Myconos, G. (2018). Identifying the defining features of flexible learning options. In S. McGinty, K. Wilson, J. Thomas, \& B. Lewthwaite (Eds.), Gauging the value of education for disenfranchised youth (pp. 28-41). Leiden, Netherlands: Brill Sense.

Noddings, N. (1984). Caring: A feminine approach to ethics and moral education. Berkeley: University of California Press.

Organisation for Economic Co-operation and Development (OECD). (2010). Off to a good start? Jobs for youth. Paris, France: OECD.

Organisation for Economic Co-operation and Development (OECD). (2012). Equity and quality in education: Supporting disadvantaged students and schools. Paris, France: OECD.

Organisation for Economic Co-operation and Development (OECD). (2013). PISA 2012 results: Ready to learn; students' engagement, drive and self-beliefs (Vol. 3). Paris, France: OECD.

Organisation for Economic Co-operation and Development (OECD). (2016). PISA 2015 results: Excellence and equity in education (Vol. 1). Paris, France: OECD.

Organisation for Economic Co-operation and Development (OECD). (2017). Educational opportunity for all: Overcoming Inequality throughout the life course. Paris, France: OECD.

Office of the Children's Commissioner. (2013, April 24). "Always someone else's problem": Office of the Children's Commissioner's Report on illegal exclusions. London, UK: Office of the Children's Commissioner.

Ofsted. (2016). Alternative provision: The findings from Ofsted's three-year survey of schools' use of off-site alternative provision. Manchester, UK: The Office for Standards in Education, Children's Services and Skills.

Quinn, J., \& Dryfoos, J. (2009). Freeing teachers to teach: Students in full-service community schools are ready to learn. American Educator (Summer), 16-21. 
te Riele, K., McGregor, G., Mills, M., Baroutsis, A., \& Hayes, D. (2020, December 17). Learning from alternative schools to enhance school completion. In Oxford Research Encyclopaedia of Education. Oxford University Press.

Rotgans, J. I., \& Schmidt, H. G. (2012). Problem-based learning and student motivation: The role of interest in learning and achievement. In G. O'Grady, E. Yew, K. Goh, \& H. Schmidt (Eds.), One-day, one-problem (pp. 85-101). Singapore: Springer.

Salvation Army. (2013). It's not asking too much! National economic and social impact survey 2013. The economic and social impact of cost of living pressures on people accessing emergency relief. Melbourne, VIC: The Salvation Army.

Seaton, J. (2017, March 9). More than 13 million kids in this country go to school hungry. The Denver Post. www.denverpost.com/2017/03/09/childhood-hunger-school-lunch/

Skattebol, J., \& Hayes, D. (2016). Cracking with affect: relationality in young people's movements in and out of mainstream schooling. Critical Studies in Education, 57(1), 6-20.

Skattebol, J., Saunders, P., Redmond, G., Bedford, \& Cass, B. (2012). Making a difference: Building on young people's experiences of economic adversity; final report. Sydney, Australia: UNSW Social Policy Research Centre.

Skiba, R. (2014). The failure of zero tolerance. Reclaiming Children and Youth, 22(4), 27-33.

Smyth, J., Down, B., \& McInerney, P. (2010). "Hanging in with kids" in tough times: Engagement in contexts of educational disadvantage in the relational school. New York, NY: Peter Lang.

Smyth, J., \& Wrigley, T. (2013). Living on the edge: Rethinking poverty, class and schooling; Adolescent cultures, school and society. New York, NY: Peter Lang.

Subban, P. (2006). Differentiated instruction: A research basis. International Education Journal, 7(7), 935-947.

Tarc, P. (2009). Global dreams, enduring tensions: International baccalaureate in a changing world. New York, NY: Peter Lang.

Taylor, J., \& Nelms, L. (2008). Life chances at 16. Life Chances Study stage 8. Melbourne, VIC: Brotherhood of St. Laurence.

te Riele, K. (2008). Are alternative schools the answer? New Transitions, 12(1) cpb-apse2.wpmucdn.com/rde.nsw.edu.au/dist/c/8/files/2014/11/Are-Alternative-schools-theAnswer-te-Riele-2008-26d4fv7.pdf

te Riele, K. (2012). Negotiating risk and hope: A case study of alternative education for marginalized youth in Australia. In W. Pink (Ed.), Schools and marginalized youth: An international perspective (pp. 31-79). Cresskill, NJ: Hampton Press.

te Riele, K. (2014). Putting the jigsaw together: Flexible learning programs in Australia; final report. Melbourne, VIC: The Victoria Institute for Education, Diversity and Lifelong Learning.

Teese, R. (2007). Structural inequality in Australian Education. In R. Teese, S. Lamb, M. Duru-Bellat, \& S. Helme (Eds.), International studies in educational inequality, theory and policy (pp. 39-61). Dordrecht, Netherlands: Springer.

Thomson, P., \& Pennacchia, J. (2016). Hugs and behaviour points: Alternative education and the regulation of "excluded" youth. International Journal of Inclusive Education, 20(6), 622-640.

Tomlinson, C. A. (2014). The differentiated classroom: Responding to the needs of all learners (2nd ed.). Alexandria, VA: Association for Supervision and Curriculum Development.

Vadeboncoeur, J. A., \& Vellos, R. E. (2016). Recreating social futures: The role of the moral imagination in student-teacher relationships in alternative education. International Journal of Child, Youth, and Family Studies, 7(2), 307-323.

Vellos, R. E., \& Vadeboncoeur, J. A. (2013). Alternative and second chance education. In J. Ainsworth \& J. G. Golson (Eds.), Sociology of education (pp. 35-39). Thousand Oaks, CA: SAGE Reference. 
te Riele, K., McGregor, G., Mills, M., Baroutsis, A., \& Hayes, D. (2020, December 17). Learning from alternative schools to enhance school completion. In Oxford Research Encyclopaedia of Education. Oxford University Press.

Victorian Ombudsman. (2017). Investigation into Victorian government school expulsions Melbourne, VIC: Victorian Ombudsman.

assets.ombudsman.vic.gov.au/assets/Reports/Parliamentary-Reports/1-PDF-ReportFiles/Investigation-into-Victorian-government-schoolexpulsions.pdf?mtime $=20191218105017$.

Vincent, K. (2012). Schoolgirl pregnancy, motherhood and education: Dealing with difference. Stoke-on-Trent, UK: Trentham Books.

Wilkin, A., White, R., \& Kinder, K. (2003). Towards extended schools: A literature review. Nottingham, UK: National Foundation for Educational Research.

Wilkinson, R., \& Pickett, K. (2009). The spirit level: Why equality is better for everyone. London, UK: Penguin. 